\title{
RESEARCH PAPER \\ IMPLICATIONS OF COMPULSORY LAND ACQUISITION AND COMPENSATION IN GHANA: A CASE STUDY OF LAND ACQUISITION FOR THE SUAME-BUOHO ROAD RECONSTRUCTION IN KUMASI
}

\author{
R. King and D. K. Sumbo \\ Centre for Settlement Studies, College of Art and Built Environment \\ KNUST, Kumasi
}

\begin{abstract}
Most lands in Ghana are held by individuals, families, clans and stools/skins under the customary tenure. To have access to land to develop infrastructure, the government usually resorts to a legal process of compulsory acquisition. This power extinguishes all proprietary titles, interests and other rights vested in the owners of the land. Laws regulating compulsory acquisition make provision for prompt, fair and adequate compensation payments to recompense the owners of demolished property. This paper examined compensation issues related to the Suame-Buoho road reconstruction where the government used the power of compulsory acquisition to acquire lands along the road for the purpose of expanding the road. The paper sought to identify the challenges and prospects associated with the process of compulsory acquisition, assessed the fairness, adequacy and promptness of compensation and the resultant effects on the affected people. A sample of 64 affected persons and two state institutions that were involved in the acquisition were identified for data collection using questionnaire survey. The findings showed that the affected persons did not really understand the issues of compulsory acquisition, compensation payments and the requirement for them to submit claims for compensation payments. The acquisition was not properly carried out as required by law as no executive instrument was published and compensation was mainly paid in piecemeal. The paper recommends among others things that individuals affected by the acquisition should be educated on the relevance of submission of claims for compensation as well as on the need to engage valuers to represent them in the compensation assessments.
\end{abstract}

Keywords: Land, Compulsory Acquisition, Compensation, Suame-Buoho road

\section{INTRODUCTION}

In Ghana land is owned predominantly by customary authorities (stools, skins, clans and families). Together they own about $78 \%$ of all lands, the state $20 \%$ and the remaining $2 \%$ is owned by the state and customary authorities in a form of split ownership (Larbi, 2008). This arrangement of ownership has been a major problem to the government in its attempt to provide infrastructure due to its limited owner- 


\section{King and Sumbo}

ship of land. This drawback provides the government with no choice than to acquire individual lands compulsorily, resulting in the displacement of people (Adu-Gyamfi, 2012).

Compulsory land acquisition is the only power the government has to acquire private rights in land for a public purpose, without necessarily willing consent of its owner or occupant (Jonathan, 2012 citing Keith, 2008). Government usually acquires land for the provision of infrastructure such as roads, hospitals, schools, electricity, inter alia (Adu- Gyamfi, 2012). The provision of such infrastructure is expected to lead to equitable distribution of the country's resources among the rich and the poor.

Individuals everywhere fear and abhor compulsory acquisition (Properties Junction 2010). Experiences in Europe, Africa and elsewhere in the world show that if not properly handled, compulsory acquisition can cause untold political disorders (Ghansah, 2010). For example Wilbard (2010) asserts that "processes involved in land acquisition for public use in Tanzania (i.e. alienation, valuation and compensation) unless supported by clear, institutionalised and inclusive protocols, which are transparent and predicable, may result in unintended and undesirable negative consequences and grievances triggering conflicts between government and landowners".

Compulsory acquisition extinguishes the rights and the interests of the expropriated owners and vests everything in the President of Ghana who in turn delineates all or part to the acquiring authority (Larbi, 2008). That notwithstanding the implementation of the purpose of the acquisition mostly requires massive demolition of properties and interferes with existing on-going property developments especially in the urban setting (Larbi, 2008). Compulsory acquisition is intended to provide the needed land at the right location for infrastructural development but in the process of the acquisition several individual and corporate properties are demolished to pave the way (Wilbard, 2010). In such circumstances, if compensation is not paid, livelihoods and businesses are affected resulting in negative impacts of the good intention.

As stated by Ollenu (1962, cited in Botchway, 1998:528), "what is left to the owners in possession at the date of acquisition is the right to compensation". He further stressed that compensation following a compulsory acquisition of land is based on the principle of equivalence or the doctrine of "Restitutio in Integrum". Thus, an expropriated person, when compensated, should not be better or worse off than before the acquisition (Ollenu, 1962).

Compulsory acquisition is not always a smooth process. It comes with so many problems. As indicated by Blair (1980:184), "compulsory purchase is a controversial issue since by definition the vendor is often unwilling to sell". While some see compulsory acquisition as an abuse of their rights to own landed property, others think it is an opportunity for them (affected parties) to extort money from the state because the compensation paid in most cases is misconstrued to be "a large amount".

Compensation payment, as stipulated in Article 20 of the 1992 Constitution of the Republic of Ghana, is supposed to be prompt, fair and adequate (Government of Ghana, 1992). However, there have been several acquisitions without the payment of compensation at all let alone prompt, fair and adequate. In some instances, serious complications arise because the Constitution does not define 'prompt', 'fair' and 'adequate'. An instance is "the acquisition of lands in Cape Coast for the establishment of the University of Cape Coast where compensation has not been fully paid" (Larbi, 2008: 10). The acquisition was made in 1962 and since then compensation has not been fully paid. This infuriated seven affected communities to file a claim for compensation in 2004. The noncompliance with the laws regulating compensation brings about agitations and encroachment of acquired lands especially when they have not been utilized for the intended purpose. 
Even when compensation is paid, what most of the expropriated persons do not understand is that the acquiring authority is only under an obligation to reinstate them but not to improve their lives (Larbi, 2008).

Against this backdrop, the paper examines the realities on the ground regarding compulsory acquisition and compensations. To achieve this, a study was carried out on the Suame-Buoho acquisition undertaken by the Government of Ghana to expand the main access road there due to the heavy traffic on it. The paper specifically sought to; identify the prospects, challenges and effects associated with the processes of compulsory acquisition of land and payment of compensation as perceived by the affected persons; and assess the extent to which the compensation was adequate, fair and promptly paid as required by law. The paper ends with recommendations for acquisition and compensation payments in ways that would benefit both infrastructural development and those affected.

\section{METHODOLOGY}

Purposive and snowball non-probability sampling techniques were used to get respondents to gather data for this study. The purposive sampling method was used because the inhabitants along the Suame-Buoho road had the essential information for the study and therefore were the main target sample frame. The snowball sampling technique was also adopted to effectively locate the affected persons as many of the affected inhabitants were displaced by the acquisition and had consequently moved to different locations within and out of the study area. The sampled individuals constituted those affected by the compulsory acquisition. Upon consultation with interviewees and some leaders of the communities, these people were located and interviewed.

Two main sources of data were identified. They comprised the primary and secondary sources. A total of 64 affected household heads or their representatives were contacted to provide the primary data through focus group discussions, questionnaire survey and observations. Institutions including the Ghana Highway Authority (GHA), Department of Urban Roads (DUR) and the Lands Commission (LC) were interviewed as key informants for primary data as well. A database of all affected persons and records of compensation claims were also obtained from the Lands Valuation Division (LVD) and studied. The data collection took place in 2014.

Relevant data from books, journals, articles and papers in relation to compulsory land acquisition, and compensation were also reviewed and analysed as secondary data. These include data on categories of land ownership extracted from Deininger (2003) and data on outstanding compensation payments on major land acquisitions in Ghana obtained from Larbi (2008). Also, relevant Sections of the Lands (Statutory Wayleaves) Act, 1963 (Act 186), the State Lands Act, 1962 (Act 125), the State Lands Regulations 1962 (L.I. 230) and Article 20 of the 1992 Constitution of the Republic of Ghana were also reviewed. All major enactments regulating compulsory acquisition of property in Ghana were reviewed.

Qualitative data collected from questionnaire, interviews and focus group discussions were grouped into thematic areas and relevant information extracted and analysed. Also, quantitative data collected from the field were edited, classified, coded and quantitatively analysed using the Statistical Package for Social Sciences (SPSS). The results were presented in the form of tables and charts before the analyses and discussions.

\section{COMPULSORY LAND ACQUISITION AND COMPENSATION PAYMENTS}

Countries are faced with finding the balance between the public need for land on one hand and the protection of private property rights on the other hand. This is due to ever increasing population over the years which in turn in- 


\section{King and Sumbo}

creased the demand for land for national development and other uses (FAO, 2008). It therefore becomes essentially indispensable for the state to acquire private land for public use despite its responsibility to safeguard the security of private land ownership. "Compulsory acquisition is the power of government to acquire private rights in land without the willing consent of its owner or occupant in order to benefit society. It is a power possessed in one form or another by governments of all modern nations. This power is often necessary for social and economic development and the protection of the natural environment" (FAO, 2008:5). Despite its necessity, compulsory acquisition is said to be inherently disruptive. Even when compensation is generous and procedures are generally fair and efficient, the displacement of people from established homes, businesses and communities will still entail significant human costs, including the hidden ones. Where the process is designed or implemented poorly, the economic, social and political costs may be enormous (FAO, 2008:5).

A case cited in Property Junction (2010), declared many years ago in the case of Pennsylvania Coal Company versus Mahon that take, and you must compensate, regulate and you need not compensate. Compensation, whether in financial form or as replacement land is at the heart of compulsory acquisition and not by mere government regulations as in town planning controls. As a direct result of government action, people lose their homes, land and their means of livelihood. The purpose of compensation is to repay them for these losses (FAO, 2008). The 1992 Republican Constitution of the Republic of Ghana states in Article 20(2) that compulsory acquisition of property by the state shall only be made under a law which makes provision for the prompt payment of fair and adequate compensation. Similarly, Rwanda's Constitution in Article 29 states that "Private property, whether individually or collectively owned, is inviolable. The right to property may not be interfered with except in public interest, in circumstances and procedures determined by
Law and subject to fair and prior compensation" (Government of Rwanda, 2010:12). Regrettably, the Constitution of the Republic of Ghana failed to provide into details what should constitute prompt, fair and adequate compensation. This has been left to judicial and professional decisions.

\section{THE REGULATORY FRAMEWORK FOR COMPULSORY ACQUISITION AND COMPENSATION IN GHANA}

\section{Interests and rights to land}

Interests and rights in land are the subject matter of compulsory acquisition and when the acquisition process is completed they become vested in the President of the Republic of Ghana to hold for and on behalf of the people of Ghana (Ayitey et al, 2010). According to section 19 of the Land Title Registration Law, 1986 (PNDCL 152), four types of interests exist in land in Ghana and these are the allodial, customary freehold, the leasehold and customary tenancies. When the power of compulsory acquisition is exercised, these rights are either limited or extinguished altogether and compensation is usually paid in money terms to recompense the loss of these interests and rights. Notwithstanding this, Larbi (2008) confirms that currently, no compensation is paid directly to holders of customary rights such as the customary freehold. All such holders are expected to be compensated by the head of the landowning community to whom the compensation for the allodial interest is paid.

\section{Compulsory acquisition process in Ghana}

Compulsory acquisition as laid out in the State Lands Regulations for the purpose of highway is carried out by the Ghana Highway Authority (GHA) on behalf of the President of the Republic of Ghana. Whenever land is to be acquired for a highway road construction, enquiries are made by the GHA at the Lands Commission regarding the land. Also an approval is sought from the Department of Town and Country Planning to ensure that the proposed acquisition conforms to the planning regulations of the area as well as a survey report from the Survey and 
Mapping Division of Lands Commission, which will be accompanied with a site plan. A formal application is then submitted to the Regional Minister of the region within which the land is situated together with the site plan. Upon receipt of the application, the Regional Minister then requests the District Chief Executive of the area to set up a committee comprising experts from Town and Country Planning Department, Survey and Mapping Division, Land Valuation Division, Environmental Protection Agency, and Utility Services. The District Chief Executive chairs the committee. The committee is mandated to inspect the land and make enquiries to the effect that:

- there is no alternative land which can be used for the intended project;

- the social and environmental impact of the proposed project on the people had been assessed;

- technical expertise of the acquiring authority (in this case GHA and DUR) is adequate for the project; and

- whether or not the acquiring authority has sufficient funds to undertake the proposed project as well as to compensate the affected persons.

The committee after satisfying the above submits a report and recommendations to the Regional Minister for his signature signifying approval or otherwise. Upon approval by the Regional Minister he submits the plans to the sector Minister responsible for lands (currently the Minister of Land and Natural Resources) for his approval as well. From this point it is forwarded to the Executive Secretary of the Lands Commission. The Lands Commission together with the Director of Survey and Attorney General Department will then get an Executive Instrument published.

Publication of the Executive Instrument formalizes the acquisition and affected persons then submit their claims for compensation. The above procedures and the activities of the committee show that there is no legal requirement to involve the affected persons in the process prior to the publication of the executive instrument (Section 1, State Lands Regulations 1962, L. I. 230). As to whether or not the process is even followed is an issue this paper sought to investigate.

\section{Basis for the assessment of compensation}

Compensation is usually assessed based on principles laid down by law in the State Lands Act, 1962 (Act 125). As affirmed by Ayitey et al (2006) (as cited in Ayitey et al, 2010:33) "The determination of the amount of compensation in monetary terms is by the process of valuation in which values are not created, but arrived at through the application of relevant economic and legal principles". In Ghana, the principal enactment that regulates compensation assessment is the State Lands Act, 1962 (Act 125) and its amendments. In section 4 of Act 125, the various claims for which an expropriated owner may make to be compensated are market value of the land (and buildings) taken, or replacement value of the land taken, cost of disturbance, other damage (severance and injurious affection), or grant of land of equivalent value.

\section{FINDINGS}

\section{Location and types of developments affected by demolition}

The predominant land use along the SuameBuoho stretch of the Kumasi-Techiman highway is commerce. These include banks/ financial institutions, fuel stations, stores for building materials, provisions and pharmaceuticals, salons, cold stores and chop bars. The next dominant land use is residential in the form of family houses, hotels and guest houses. These are made up of a mixture of single and multistorey buildings along the road. Most of these developments are predominantly built of sandcrete blocks. However, there are more multi storey buildings on the western side of the road than on the eastern side. Most of the single 


\section{King and Sumbo}

storeys structures are built of landcrete. In addition, there are several temporary mounted wooden structures along the road that are being used as workshops.

\section{Compulsory land acquisition process}

By section 1(1) of the State Lands Act, 1962, Act 125 , compulsory acquisition is only effected upon the publication of an Executive Instrument. Also, by Article 20 of the 1992 Constitution of the Republic of Ghana, compulsory acquisition shall only be undertaken under a law which makes provision for the payment of compensation. However, information provided by the Ghana Highway Authority indicates that no specific law was used for the acquisition and therefore no executive instrument was published. Therefore, in principle, the acquisition undertaken could be said to be incomplete in going through the legal procedures.

According to the State Lands Regulation, L.I. 230 , before an executive instrument is published a site advisory committee must be set up to advise the acquiring authority about the feasibility, suitability or otherwise of the intended acquisition and whether or not there is alternative land for such project. According to the Public and Vested Lands Management Division (PVLMD) of the Land Commission (LC), in the Suame-Buoho land acquisition, a site advisory committee was not formed to advise the acquiring authority of the intended acquisition. Only a committee of experts was formed by the National Headquarters of GHA to carry out the project. When asked why these requirements were not adhered to, the Department of Urban Roads explained that the project was required to commence immediately due to pressure from funding agencies and the government.

Involvement of the affected people in the acquisition process

According to Pham et al (2013), participation of affected people in acquisition programmes helps diminish adverse effects and severe vulnerability and thus enhances the chances of success for displaced people to adapt to new places. Also, a World Bank study specified that the level of participation in a resettlement programme must be elevated to encompass collaboration and involvement in decision making instead of mere consultation (World Bank, 2004). The findings show that in the SuameBuoho land acquisition, a scoping exercise was carried out by the committee of experts and meetings were organized for people whose properties were marked to be acquired. The respondents however claimed they had no knowledge of the acquisition prior to the marking of their walls, suggesting that it was possible that not all affected persons were privileged to attend such meetings. Upon cross-checking with the GHA and DUR, these two institutions affirmed the respondents' claims and attributed this to the hasty nature of the road reconstruction project. The State Lands Regulations show that affected people are required to be involved in compulsory acquisition at the site advisory committee stage. But the realities on the ground revealed contrary processes.

\section{Properties affected by the acquisitions}

Fig. 1 represents the proportion of respondents that made various uses of the land compulsorily acquired from them for the Suame-Buoho road reconstruction. Thirteen per cent of them had lands that were yet to be developed, while $61 \%$ of the respondents said they had buildings at the acquired site prior to compulsory acquisition. Others $(23 \%)$ also had metal containers and kiosks on their lands at the site. Some of the respondents $(3.2 \%)$ complained the pavement they made in front of their kiosks/ containers or houses as walkways and part of the properties on their land was affected and destroyed as part of the acquired land. The above shows that lands with buildings were intensely affected than the others. Thus, the expropriated persons were greatly affected because demolition of some properties were carried out immediately whilst compensation was delayed. Generalization of the proportion of persons affected as a result of the acquisition means a great loss of buildings to the power of compulsory acquisition. 

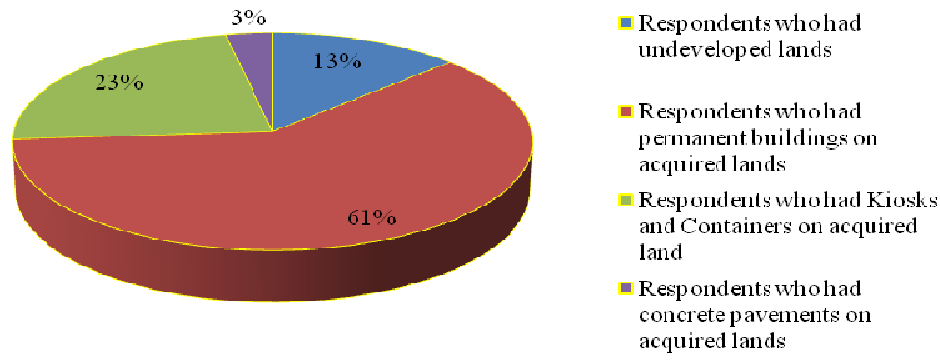

- Respondents whohad concrete pavements on acquired lands

Fig. 1: Respondents with different property types on acquired lands

\section{Submission of claims for compensation}

When the state resorts to the power of compulsory acquisition, the law requires that the owner of the property is entitled to "the payment of prompt, fair and adequate compensation". An owner is entitled not only to the value of the land and/or building but also for all losses he may suffer in consequence of the acquisition. A responsibility then lies with the expropriated party to claim for the compensation.

According to section 4 of the State Lands Act, 1962 (Act 125), upon the publication of the Executive Instrument, anybody whose interest is affected in any manner is obligated to submit a claim in writing to the Lands Commission for compensation within a period of six (6) months from the date of publication of the Executive Instrument. In this acquisition, 58 of the respondents representing $90.3 \%$ said they did not submit claims for compensation whiles only 6 respondents $(9.7 \%)$ said they submitted claims for compensation. However, interaction with some of the respondents who said they submitted claims revealed that they only did so after the compensation was paid. This confirms the
LVD's position that only few respondents submitted claims for compensation but after compensation was paid and affected person were not satisfied with the amounts paid. The above suggests that the Land Valuation Division unilaterally determined the compensation payable to them, which also suggests that the monetary value paid could be less or more than the value of the properties demolished since the government body effecting the acquisition is also expected to determine the compensation to be paid without inputs from the affected parties.

The requirements for submission of a claim are technical and the expropriated party cannot submit a claim without the assistance of a valuer. The data collected however showed that only $10(15 \%)$ of the respondents said they involved valuers as against 54 respondents $(85 \%)$ who did not involve a valuer. Most of the affected people who did not submit claims for compensation said they did not understand what that meant and the implications. It is likely that involvement of valuers would have led to an increase in submission of compensation claims therefore leading to most likely a 


\section{King and Sumbo}

fair compensation assessment since the valuers would represent the affected people in the process and the cost of involving valuers is paid by the government.

\begin{abstract}
Assessment of compensation
According to the LVD, every assessment of value must have a basis upon which the value is determined. The basis for the assessment of compensation is stated in Section 4(3a-c) of the State Land Act, 1962 (Act 125). These include the market or replacement value of the land and building (s), the cost of disturbance or any other damage suffered thereby and the benefits to be derived by the people of the area in which the land is situated, from the use for which the land is acquired (in this case, from the road). The LVD stated that in assessing the compensation at this acquisition, they considered the market value of the land, the replacement value of the buildings and the cost of disturbance and any other damages suffered. Nonetheless, they did not consider the benefits to be derived by the people in the area and no reason was given for that. All things being equal, the compensation paid would be bloated since the factor that was excluded from the assessment process was supposed to be deducted from the compensation value to offset the benefits the affected people would derive from the use of the road.
\end{abstract}

\section{Adequacy, fairness and promptness of com- pensation}

Article 20 clause 2(a) of the 1992 Constitution of the Republic of Ghana stipulates clearly that compulsory acquisition of land shall only be made under a law which makes provisions for the prompt payment of fair and adequate compensation. This means that the assessed value must be fair both to the expropriated persons and the acquiring authority. However, the expropriated persons in this particular acquisition considered the compensation inadequate as most of them were not satisfied with the compensation. This is because they said the money paid could not in any way rebuild or replace the properties demolished especially when inflation at the time was rapidly increasing. It is most likely that the compensation might be unfair due to the fact that most of the expropriated persons did not play a role or were not represented in the assessment of the compensation. Also, delays in paying compensation affected the value of money in the long run which made it unfair. All the heads of claim under Act 125 were duly considered in the compensation assessment with the exception of 'benefits to be derived by expropriated use to which the land is put to'.

Thirty-one (31) expropriated persons, representing $48.7 \%$ of the respondents said they were not satisfied with the compensation while 24 persons representing $37 \%$ said they were satisfied with the compensation and the remaining $14.3 \%$ said they were not paid compensation even though they said they held title to their properties that were compulsorily acquired. Thus, the majority of the expropriated persons were not satisfied and felt the compensation was inadequate. Even when the affected parties were satisfied with the compensation amount paid to them, the fact that money cannot be used to measure all damages caused to property is an inevitable challenge faced by property owners. Thus, financial awards may be inadequate to compensate for all other nonmonetary losses and to allow people to enjoy sustainable livelihoods after their land is acquired. People may feel that they are not compensated for the loss of cultural, religious or emotional aspects of the land (FAO, 2008). When compensation is not paid at all, the effect is felt more since property owners cannot replace the demolished property and this substantially affects their livelihood. According to Innes (2000), where people are not compensated or feel cheated, they can act to inhibit the purpose for the acquisition of their land.

\section{Promptness of compensation}

The 1992 Constitution of the Republic of Ghana provides for prompt payment of compensation in Article 20(2a) as a condition for compulsory acquisition of land. Also, Act 125 provides that submission of claims should be 
made within a period of six months after publication of the Executive Instrument (E.I.) Actual payment of compensation can therefore start only after a period of six months. This also implies that a gap is created between the time of demolition of property and the time for reproduction of same. This gap adds to the default long period that is usually needed to build landed properties. In the Suame-Buoho acquisition, 4 persons $(6.5 \%)$ were paid their compensation within one year, 37 persons $(58.1 \%)$ in the second year, 2 persons $(3.2 \%)$ in the third year and 8 persons $(12.9 \%)$ within the fourth and fifth years. Thus, the compensation was paid in piece-meal with the highest percentage $(58.1 \%)$ paid within the first year. The compensation on the average was paid within a two year period. From the information above, it can be reasonably concluded that compensation payments were on the average prompt. This is because according to Act 125, affected persons can only submit their compensation claims after six months, and the LVD needs not less than another six months to assess the compensation depending on the intensity of the work involved. Therefore, the word "prompt" as stated in the law cannot reasonably be less than 1 year.

However, some expropriated persons were paid beyond two years in this instance. This raises the question of what happens to the economic and livelihood activities that were supported by such properties prior to the acquisition within this lapse of time. Also, five persons representing $7.8 \%$ said they were not paid compensation at all though their lands/buildings were affected. The LVD admitted that there were outstanding compensation payments but funds were not readily available to effect the rest of the payments.

\section{Effects of compulsory acquisition and com- pensation}

The execution of compulsory acquisition and compensation at Suame-Buoho had both positive and negative effects on the expropriated owners and their families as presented below.

\section{Negative effects}

Forty-three of the respondents, representing about $66.7 \%$ claimed their living conditions became worse-off after the acquisition. The study found that these effects were family disunity, congestion, dust evading rooms due to partial demolition of the habitable house, loss of business customers and profits, general insecurity and difficulty in renting new accommodation.

\section{Family disunity}

Relocation and family disunity was experienced in two ways by the expropriated individuals. In the first place, some parts of buildings were affected by the compulsory acquisition and so were demolished. This resulted in the need for some family members to relocate thereby breaking close family bonds due to distance. Secondly, there were disputes over the sharing of compensations paid leading to divisions. Compensation paid was to serve a good motive but it became a source of unrest to some families.

\section{Congestion}

Another problem faced by the expropriated individuals and families was congestion given the limited space they now had to contend with after the compulsory land acquisition. As a result of severance of their properties, thirteen family members had to join others in their rooms. As complained by the respondents, this created overcrowding in the rooms which led to loss of privacy.

\section{Dust pollution}

Expropriated persons who used their properties along the road as living spaces complained that the demolition and road construction exercises produced so much dust pollution which entered their rooms and discoloured their belongings and walls, rendering the place dirty and unattractive, whilst those who used their buildings for business activities complained of customer dissatisfaction with their products because of the dust. Most especially, owners of restaurants that are located along the road complained they 


\section{King and Sumbo}

were particularly disturbed by the dust. In a particular case illustrated in Plate 1 below, the frontage of the house was taken which made the house very close to the road expansion exercise and consequently exposed it to too much noise and dust from the construction site. Consequently, the building was no longer habitable. On the basis of assessment of compensation, this effect falls under what is referred to as 'other damages', specifically 'injurious affection' and must be compensated for. An interview with one of the affected persons however revealed that she had made several complains to the authorities responsible for paying compensation but this did not lead to any successful outcome. He said the authorities complained that she had already been compensated. A cross check saw the LVD admitting that the demolition and construction at that area was done after payment of compensation and such injuries were not taken into account in the compensation assessment.

Relocation of businesses

Having lost their property to the road construc- tion, some affected persons relocated their shops and businesses farther away thereby losing customers and facing more difficulties in operating the businesses than before. They complained that they had lost their customers and those customers who will attempt relocating them will be inconvenienced. They complained about losing customers they had established goodwill relations with over a long period of years and had to start building new customer relationships all over again. In some cases too, owing to the disturbances, some affected people had given up business altogether.

\section{Access difficulties}

Six expropriated individuals, representing 9.4\% of the respondents complained of difficulty in accessing their houses. They said during the time of construction and demolition the entrances to their houses were blocked. As a result, they said they had to park their vehicles outside. In some cases too, the people complained that no footbridges were created after the construction of gutters in front of their houses. They had to construct the bridges at

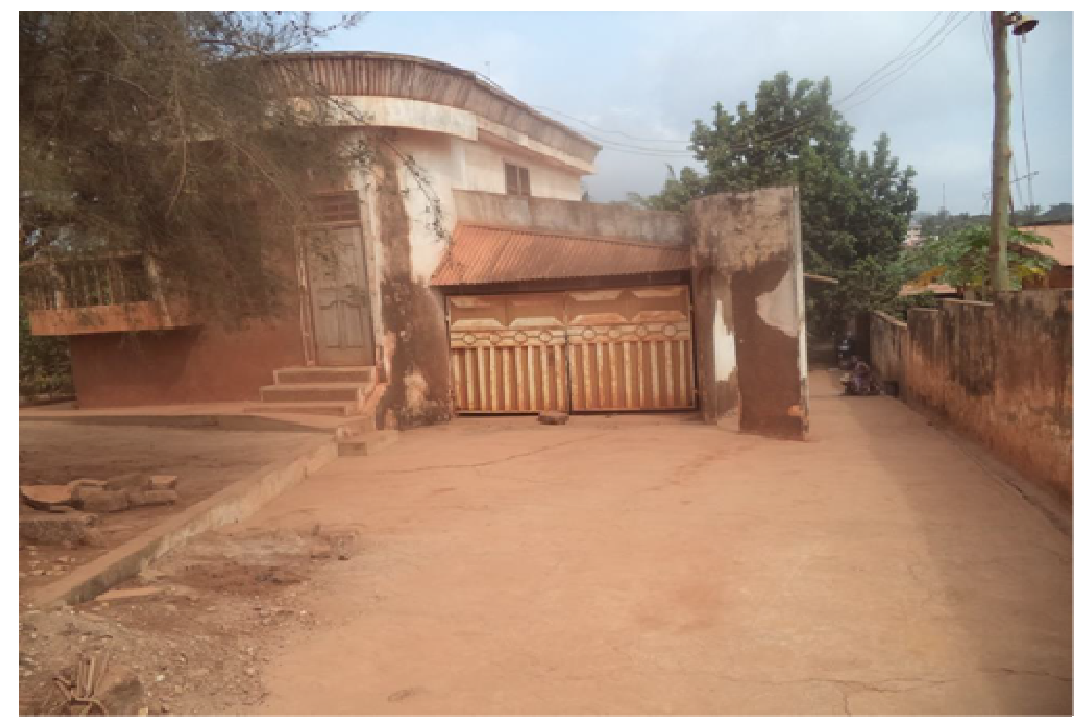

Plate 1: A large property rendered inhabitable due to too much dust pollution

Journal of Science and Technology @ KNUST August 2015 
their own cost. This they said was not recompensed.

Furthermore, seventeen $(26.6 \%)$ respondents said the new road was higher in altitude than the old road, increasing the angle of depression of vision of passengers and pedestrians. This made activities in their houses to be easily seen over the walls causing invasion of privacy. Others had to construct steps to enable customers to access their services.

\section{Insecurity}

General insecurity was another problem property owners complained of. The demolition of the frontages and security walls of some houses rendered them open. They further complained that this gave room to stealing and robbery in their houses. One property owner remarked, as he grumbled that "until the fence walls are built, our houses will continue to face insecurity".

\section{Delays and inflation}

Building cost escalation was another problem the property owners said they faced. They mentioned that the sharp increase in cost of building materials due to high inflation rate led to an abrupt increase in building cost. The effect was that the real value of their compensation amounts diminished very fast and soon rendered the compensation amounts inadequate to afford new buildings in place of the demolished ones.

It was noted from the survey that some compensation payments were unduly delayed. Ten (15.6\%) respondents were paid their compensation after three years. This delay negatively affected the expropriated persons who said they were traumatised for the period of the delay, anticipating the payment of their compensations.

Twenty-eight respondents representing $43.7 \%$ of the respondents also complained of having to rent new places with their own moneys during the period of delay. Forty-six respondents re- presenting $71.8 \%$ of the respondents further indicated that they made extra efforts through several visits to the office of the LVD of the Land Commission with associated transportation costs and time which were not factored into the compensation payments. An effect linked to the above statement was the delay in undertaking the road construction as $18.33 \%$ of the affected persons prevented the demolishing team from pulling down their structures because their compensations were yet to be paid. They wanted their monies before they would allow for their structures to be brought down. This in turn delayed the scheduled time for the road reconstruction, which also contributed to the late completion of the project. This suggests that, a good dialogue between the authorities and the affected individuals would have helped the affected persons to appreciate the process better.

\section{Compensation paid in piece-meal}

Compensation was paid in piecemeal to expropriated persons. Twenty-six persons representing $40.6 \%$ of the respondents were paid only a token amount as early as possible to allow for demolition and the remaining paid later. This made it difficult for them to use such small amounts of money to rent new accommodation for shelter and shops to immediately continuebusiness activities and to get on with their lives. Worst of were those expropriated persons who had not been paid compensation at all. The LVD confirmed that not all the expropriated persons were compensated. About 17 persons representing $26 \%$ of respondents were not paid compensation. All these negatively affected economic and social activities that were supported by the demolished properties and hence the livelihoods of the people.

\section{Positive effects}

Apart from the road being reconstructed to ease traffic, the data revealed that the acquisition brought improvement in the living conditions of 11 individuals, representing $17.2 \%$ of the respondents. From the research it was revealed that two major positive effects brought im- 


\section{King and Sumbo}

provement to the affected persons as a result of the demolition for the reconstruction of the road. These are the building of sandcrete structures in place of the landcrete houses. Secondly, twenty persons, representing $31.3 \%$ of the respondents said they had acquired new structures with larger spaces with the compensation paid to them. Thus, before the acquisition, this category of expropriated persons was living in structures with small spaces. It goes to say that compulsory acquisition does not only negatively affect the expropriated persons and their properties but it also brings improvement.

\section{RECOMMENDATIONS}

Having noted the challenges displaced individuals faced as a result of compulsory acquisition of their properties by the state, the following recommendations are made to address some of the problems. It is recommended that the Ghanaian populace should be educated on the need to register their interests inland with the land related institutions such as the Lands Commission, the Office of the Administrator of Stool Lands, and the Land Administration Project (LAP). Departments in various tertiary institutions such as the universities and polytechnics whose programmes are related to land like Land Economy and Estate Management can contribute to address this challenge nationally. This could be done through seminars, symposia, forums in both rural and urban communities. The above departments should also liaise with traditional authorities to educate their people during durbars and festivals.

Executive Instruments of compulsory land acquisitions should be published as required by law and copies should be sent to the respective affected persons, institutions and bodies that are involved in the compulsory acquisition process. When this is done, it will validate the acquisition, enhance the process of the acquisition and significantly reduce the effects of the acquisition on individual properties and their associated complementary uses.

The L.I 230 should be amended to make it a requirement to involve the prospective affected persons prior to the publication of the Executive Instruments. This should be done by the Site Advisory Committee by organizing forums and seminars for prospective affected persons before a recommendation is made to the Regional Minister. In this manner the affected persons will contribute to and have their grievances addressed at an early stage.

The Site Advisory Committee must explain the concepts of compulsory acquisition and compensation to the people to be affected prior to the demolition. This sensitisation should cover the laws backing it, why it must be undertaken, the benefits to be derived from it and the fact that certain losses are inevitable but can be minimised. Compensation must also be explained in terms of its components, what it stands for and how to utilize it as well as why it is even given to expropriated persons. According to the FAO, as a direct result of government action, people lose their homes, their land, and at times their means of livelihood. Compensation is to repay them for these losses, and should be based on principles of equity and equivalence. Such explanation will make the affected persons accept certain consequences, make good use of the money paid to them and support the project.

The paper also recommends that the government could establish an independent body of experts to determine the fairness and adequacy of compensation after it has been assessed by the Lands Commission or to be vested with the entire responsibility of assessment of compensation in such a body.

The authors recommend that compensation approval should be decentralized to facilitate the timely approval of compensation for prompt payment. To achieve this, approval committees should be set up at the regional offices instead of only the national office.

It is recommended that in order not to further frustrate property owners, full compensation 
should be paid before demolition especially where a person's livelihood or business is directly linked to the affected property. To achieve this, the Lands Commission through the Site Advisory Committee should obtain reliable information and commitment that the acquiring authority has funds available for compensation payment before initiating the compulsory acquisition process or this should be done simultaneously.

Further, it is recommended that compensation must not be given to the family heads or landlords alone but everyone should be compensated according to the interest or rights held in the property. Payment of compensation to every one according to the interest or rights they held in the property will eliminate the dispute that arises over sharing of compensation payments.

Since the gestation period of putting up another building or acquiring another property is quite long, the possible increase in building cost within the period of putting up the building should be factored into the compensation package with regard to inflation. These will solve the problem of the inadequacy of compensation due to building cost escalation.

\section{CONCLUSION}

In conclusion, it is noted that compulsory acquisition of land is necessary for undertaking major developmental projects in the country, but taking a clue from FAO (2008) unfair procedures for the compulsory acquisition of land and inequitable compensation for its loss can reduce land tenure security, increase tensions between the government and citizens, and reduce public confidence in the rule of law. The findings gathered in this study uncovered that the benefits that expropriated persons derive from the acquisition are far less than the losses that they incur. In view of this, various recommendations were made to help reduce the negative effects of the compulsory acquisition and compensation on the expropriated parties. It is hoped that these recommendations will be taken into consideration by the authorities to improve upon the compulsory acquisition process and compensation payments in Ghana to enhance land tenure security.

\section{REFERENCES}

Adu-Gyamfi, A. (2012). An overview of Compulsory Acquisition in Ghana: Examining its Applicability and Effects. National Research Center for Settlement. 1 Xikang Road, 210098, Nanjing Province, China: Hohai University.

Ayitey, J. Z., Kidido, J. K. and Tudzi, E. P. (2010). Compensation for Land Use Deprivation in Mining Communities, the Law and Practice: Case Study Of Newmont Gold Ghana Limited. The Ghana Surveyor, 4 (1):32-40

Blair, A. M. (1980). Compulsory Purchase: A neglected Factor in the Agricultural Land Loss Debate, Area 12(3): 183-189.

Botchway, N. F. (1998). Land Ownership and Responsibility for the Mining Environment in Ghana. Natural Resources Journal, 38: 509-536.

Government of Rwanda (2010). Rwanda's Constitution and its Amendments. Government of Rwanda. Accessed on 20/05/2014, www.rwandahope.com/constitution.pdf

Deininger, K. (2003). Land policies for growth and poverty reduction. A World Bank Policy Research Report 1 (Report Number; 26384). Washington, DC: World Bank Group. Accessed on: 17/05/2014, from http:// d ocuments.worldbank.org/curated/ en/2003/06/2457830/land-policies-growthpoverty-reduction.

Food and Agricultural Organization (FAO), (2008). Compulsory acquisition of land and compensation, Electronic Public Policy and Support Branch. Rome: Italy. Ghana: Policy and Praxis, Land Use Policy, 1(2): 115- 127. 


\section{King and Sumbo}

Ghansah, A. W. (2010). Compulsory Acquisition and Issues Arising: A Case Study of University of Cape Coast Acquisition. Core Values Property Junction. Accessed on 7th February, 2014, http// properties junction. blogspot.com

Government of Ghana (GoG) (1992). Constitution of the Republic of Ghana. Republic of Ghana. Accessed on $18^{\text {th }}$ May, 2014, from http://www.ghana.gov.gh/images/documents/ constitution_ghana.pdf

Innes, R. (2000). “The Economics of Takings and Compensation When Land and its Public Use Value are in Private Hands", Land Economics, 76(2): 195-212.

Jonathan, M. L. (2012), Compulsory Acquisition of Land and Compensation in Infrastructure Projects. PPP Insights, 1(3):1-10

Larbi, W. O. (2008), Compulsory Land Acquisition and Compensation in Ghana, Searching for alternative policies and strategies. FIG/FAO/cng International seminar on state and public sector land management. September 9-10, 2008, Verona: Italy.

Ollenu, N. A. (1962). Principles of Customary Land Law in Ghana. London: Staples Printers Limited of London and Rochester. The
International and Comparative Law Quarterly, 14 (2): 713-715

Pham, H. T., Westen, M. V. and Annelies Z. (2013). Compensation and Resettlement Policies after Compulsory Land Acquisition for Hydropower Development in Vietnam: Policy and Practice. Land, 2:678-704. Accessed on: 18th May 2014, fromwww.mdpi.com/ journal/land/

Property Junction. (2010). Compulsory Acquisition as Legal Constraints on Land and Ownership Rights in Ghana. Accessed on $14^{\text {th }}$ May, 2014, http:// properties junction. blog spot.com/2010/09/compulsoryacquisition-as-legal.html

Wilbard, K. (2010). Land Conflicts in Dar Es Salaam: Who Gains? Who Loses? Crisis States Working Papers Series No.2 ARDHI University. ISSN 1749-1797 (print) ISSN1749-1800 (online)

World Bank, (2004). Involuntary Resettlement Sources Book: Planning and Implementation in Development Projects; The International Bank for Reconstruction and Development, Washington, DC, USA. Accessed on: $10^{\text {th }}$ April 2014, fromhttp://dx.doi.org/10.1596/08213-5576-7 